\title{
INTENSI KEWIRAUSAHAAN MAHASISWA PERGURUAN TINGGI NEGERI DI KOTA BANDUNG
}

\author{
Oleh: Rafika Rahmadani \\ rafika@stkipnurulhuda.ac.id \\ (Program Studi Pendidikan Ekonomi STKIP Nurul Huda Sukaraja)
}

\begin{abstract}
Abstrak-Penelitian ini bertujuan mengetahui gambaran intensi kewirausahaan mahasiswa di Indonesia. Penelitian ini dilakukan karena isu pengangguran yang disebabkan oleh kompetensi keahlian lulusan belum memenuhi pasar kerja dan lulusan prodi ilmu sosial kalah bersaing dengan prodi bidang keteknikan.. Penelitian ini menggunakan metode survey dengan populasi penelitian seluruh mahasiswa Perguruan Tinggi Negeri Berbadan Hukum di Kota Bandung Fakultas Ekonomi dan yang berjumlah 450 mahasiswa yang tersebar di 11 perguruan tinggi negeri. Sedangkan sampel pada penelitian ini diambil sebanyak 212 mahasiswa dari tiga perguruan tinggi. Hasil penelitian menunjukan bahwa gambaran intensi kewirausahaan mahasiswa khususnya di perguruan tinggi negeri berbadan hukum Kota Bandung menunjukkan hasil yang tinggi.
\end{abstract}

Kata Kunci : Intensi, Kewirausahaan, Mahasiswa, Bandung

\begin{abstract}
This study aims to describe the entrepreneurial intentions of students in Indonesia. This research was conducted because the issue of unemployment caused by the skills competence of graduates had not fulfilled the job market and graduates of social science study programs were unable to compete with engineering study programs. This study used a survey method with the research population of all students of State Universities with Legal Entities in Bandung City, Faculty of Economics and which amounts to 450 students spread across 11 state universities. While the sample in this study was taken as many as 212 students from three universities. The results showed that the description of the entrepreneurial intentions of students, especially in state universities with legal.
\end{abstract}

Keywords: Intention, Entrepreneurship, Students, Bandung

\section{PENDAHULUAN}

Dalam

pendidikan

lingkungan kewirausahaan di permasalahan yang dihadapi antara lain adanya isu pengangguran. Hal tersebut diasumsikan ada faktor yang mempengaruhinya, yaitu: kompetensi keahlian lulusan perguruan tinggi belum memenuhi kebutuhan pasar kerja, lulusan perguruan tinggi (prodi ilmu-ilmu 
sosial) kalah bersaing dengan lulusan dari program studi bidang keteknikan di dunia kerja. Sementara itu, lulusan program studi teknik banyak dibutuhkan namun kompetensi keahliannya masih belum memadai (Hendarman, 2011).

Jumlah angka pengangguran terbuka menurut pendidikan tertinggi. Data tersebut menunjukkan bahwa hingga Februari 2017 menunjukkan dari sebanyak 7.005.262 orang pengangguran, lulusan universitas atau tingkat sarjana menyumbang angka pengangguran sebesar 606.939 orang, sementara lulusan diploma I/II/III atau setingkat akademi menyumbang angka 249.705 orang. Berdasarkan data tersebut secara jelas memberikan gambaran yang ironis, di mana semakin tinggi pendidikan seseorang, bukan berarti jaminan untuk memperoleh pekerjaan akan semakin mudah.

Angka lulusan perguruan tinggi yang setiap tahun bertambah jumlahnya, namun lapangan pekerjaan yang tersedia semakin sempit. Pihak instansi dan swasta tidak dapat diharapkan sepenuhnya, karena jumlah permintaan dan yang ditawarkan dari tenaga kerja sudah tidak berimbang dengan jumlah angka lulusan serta daftar antrian para pencari kerja. Meningkatnya jumlah pengangguran tersebut disebabkan karena mulai sempitnya lapangan pekerjaan, sehingga menyebabkan semakin banyaknya lulusan perguruan tinggi yang menganggur karena tingkat persaingan dalam melamar pekerjaan semakin tinggi. Kualitas manusia Indonesia dirumuskan dalam tujuan pendidikan nasional yang harus dikembangkan oleh setiap satuan pendidikan. Kebutuhan untuk meningkatkan kualitas pendidikan merupakan sebuah persoalan kompleks, karena untuk mewujudkannya dibutuhkan saling ketergantungan antara semua subsistem pendidikan yang harus diimbangi dengan kualitas input, proses, fasilitas pendukung, sumber daya manusia dan sumber daya lainnya (Suwatno,dkk, 2012).

Menurut beberapa analisis, baik dari Hermawan (2003:16) yang menyatakan bahwa permasalahan utama lulusan pendidikan kita adalah kemandirian. Pendidikan hanya menghasilkan sumberdaya manusia yang bersemangat ambtenaar (karyawan). Outputnya diarahkan untuk menjadi pegawai atau bekerja untuk orang lain dan mendapatkan upah. Inilah inti masalah yang menyebabkan kemiskinan dan keterbelakangan masyarakat Indonesia. Jumlah wirausahawan di Indonesia masih sangat sedikit dan tentu saja masih sangat jauh dari kebutuhan.

Intensi kewirausahaan akhirakhir ini mulai mendapat perhatian untuk diteliti karena diyakini bahwa suatu niat yang berkaitan dengan perilaku terbukti dapat menjadi 
cerminan dari perilaku yang sesungguhnya. Dalam teori planned behavior (Tjahjono \& Ardi, 2008) diyakini bahwa faktor-faktor seperti sikap, norma subyektif akan membentuk niat seseorang dan selanjutnya secara langsung akan berpengaruh pada perilaku. (Jenkins \& Johnson).

Menurut teori Katz 2003 intensi seseorang untuk melakukan suatu perilaku ditentukan oleh dua faktor, yaitu sikapnya terhadap perilaku tersebut dan norma-norma subjektif yang dirasakan dan diyakininya mengenai perilaku tersebut.

Intensi kewirausahaan akhirakhir ini mulai mendapat perhatian untuk diteliti karena diyakini bahwa suatu niat yang berkaitan dengan perilaku terbukti dapat menjadi cerminan dari perilaku yang sesungguhnya. Dalam teori planned behavior Tjahjono \& Ardi, 2008) diyakini bahwa faktor-faktor seperti sikap, norma subyektif akan membentuk niat seseorang dan selanjutnya secara langsung akan berpengaruh pada perilaku. Oleh karena itu pemahaman tentang intensi seseorang untuk berwirausaha (entrepreneurial intention) dapat mencerminkan kecendrungan orang untuk mendirikan usaha secara riil.

Menurut teori Katz intensi seseorang untuk melakukan suatu perilaku ditentukan oleh dua faktor, yaitu sikapnya terhadap perilaku tersebut dan norma-norma subjektif yang dirasakan dan diyakininya mengenai perilaku tersebut Apabila teori Ajzen ini digabungkan dengan teori Shapero dan Sokol maka terdapat variabel lain yang harus diperhitungkan dalam mempengaruhi intensi kewirausahaan seseorang yaitu tingkat perasaan yang meyakini bahwa ia mampu melaksanakan tindakan yang dikenal dengan sebutan efikasi diri.

Pendapat ini didukung oleh Hisrich, Peters dan Shepherd (2008) yang menyatakan bahwa intensi kewirausahaan akan muncul bila ia mempunyai: a) Self Efficacy entrepreneurial, yaitu keyakinan bahwa ia mempunyai kapasitas untuk menjadi wirausaha yang berhasil dan b) perceived desirability, yaitu perasaan senang ketika melakukan kegiatan berwirausaha sehingga melahirkan kreativitas-kreativitas yang dibutuhkan.

Penelitian untuk melihat aspek intensi kewirausahaan seseorang telah mendapat perhatian yang cukup besar dari para peneliti. Hal ini didasari oleh pandangan bahwa seseorang dengan intensi untuk memulai usaha akan memiliki kesiapan dan kemajuan yang lebih baik dalam usaha yang dijalankan dibandingkan dengan seseorang tanpa intensi untuk memulai usaha. Seperti dinyatakan Kruger et al (2000), intensi terbukti telah menjadi prediktor terbaik bagi perilaku kewirausahaan. Oleh karena itu, intensi dapat dijadikan pendekatan 
dasar yang masuk akal untuk memahami siapa-siapa yang akan menjadi wirausaha. (Choo dan Wong, 2006).

Model penelitian intensi kewirausahaan seseorang kurang lengkap kalau tidak melibatkan faktor kontekstual disamping faktor sosio demografi dan faktor sikap seseorang, karena ketiga kelompok faktor tersebut membentuk satu kesatuan yang integral didalam model penelitian niat kewirausahaan seseorang. Beberapa faktor kontekstual yang cukup mendapat perhatian peneliti adalah peranan pendidikan kewirausahaan dan pengalaman kewirausahaan. Secara teori diyakini bahwa pembekalan pendidikan dan pengalaman kewirausahaan pada seseorang sejak usia dini dapat meningkatkan potensi seseorang untuk menjadi wirausahawan. Beberapa penelitian menunjukkan hasil yang mendukung pernyataan tersebut. Selain pendidikan dan pengalaman kewirausahaan, dukungan pihak akademik (academic support), social support dan dukungan lingkungan usaha (Gurbuz \& Aykol, 2018) juga diduga merupakan faktor kontekstual yang berpengaruh terhadap niat kewirausahaan.

Terkait faktor sosio demografi Azhar, dkk (2018) mengetakan bahwa perbedaan jenis kelamin juga menjadi salah satu faktor penyebab perbedaan tingkat pengembalian investasi pendidikan. Pendapat tersebut menyiratkan bahwa faktor gender (jenis kelamin) dapat dijadikan sebagai salah satu alat untuk mengukur intensi kewirausahaan. Dalam penelitian ini, indikator-indikator untuk mengukur intensi kewirausahaan mahasiswa, mengikuti pendapat Katz dan Gartner (1998) dengan beberapa penambahan. Indikator tersebut meliputi : 1) sikap terhadap kewirausahaan, 2) norma-norma sosial yang dirasakan dan 3) Efikasi diri.

Berdasarkan tinjauan literatur di atas, maka dikembangkan model penelitian yang digambarkan dalam bagan berikut:

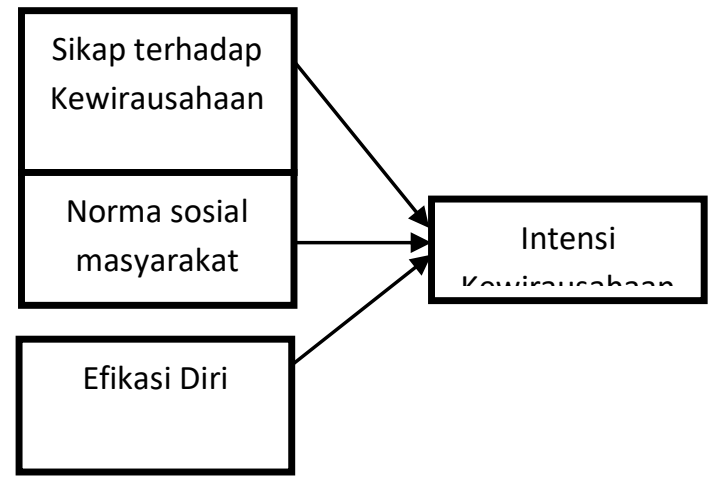

Gambar 1. Paradigma Penelitian (Sumber: Diolah, 2021) 


\section{METODE PENELITIAN}

Metode penelitian adalah "prosedur atau cara-cara yang dapat dilakukan untuk melaksanakan penelitian". Tujuan penelitian ini mencari gambaran tentang intensi kewirausahaan, maka jenis penelitian ini menggunakan metode penelitian deskriptif. Metode deskriptif adalah metode yang digunakan untuk menggambarkan atau menganalisis suatu hasil penelitian tetapi tidak digunakan untuk membuat kesimpulan yang lebih luas (Sugiyono, 2010). Metode survey adalah penelitian yang dilakukan terhadap sejumlah individu atau unit analisis, sehingga ditemukan fakta atau keterangan secara faktual mengenai gejala suatu kelompok atau perilaku individu, dan hasilnya digunakan sebagai bahan pembuatan rencana atau pengambilan keputusan.
Metode ini menggunakan kuesioner sebagai alat pengumpulan datanya (Muhidin, 2011).

\section{HASIL DAN PEMBAHASAN}

Dalam penelitian ini, pengukuran intensi kewirausahaan menggunakan tujuh indikator yang dijabarkan dalam 18 item angket. Kedelapan belas item tersebut pada hakekatnya merupakan penjabaran dari tiga dimensi intensi kewirausahaan, yaitu : 1) Sikap terhadap kewirausahaan, 2) Norma subjektif yang dirasakan di masyarakat dan 3) Efikasi diri.

Berdasarkan hasil penelitian, gambaran intensi kewirausahaan mahasiswa pada perguruan tinggi negeri berbadan hukum Kota Bandung dapat dilihat dalam tabel 1. dibawah ini :

Tabel 1. Tingkat Intensi Kewirausahaan Mahasiswa PTN BH Kota Bandung

\begin{tabular}{|c|l|l|l|}
\hline No & \multicolumn{1}{|c|}{ Dimensi } & Skor Rata-Rata & Kategori \\
\hline 1 & Sikap terhadap Kewirausahaan & 4,07 & Tinggi \\
\hline 2 & Norma sosial masyarakat & 3,65 & Tinggi \\
\hline 3 & Efikasi diri & 3,73 & Tinggi \\
\hline \multicolumn{2}{|c|}{ Total } & $\mathbf{3 , 8 1}$ & Tinggi \\
\hline
\end{tabular}

Sumber: Diolah, 2021

Berdasarkan tabel di atas, terlihat bahwa intensi kewirausahaan mahasiswa berada pada kategori tinggi atau kuat. Hasil ini menunjukkan bahwa intensi kewirausahaan mahasiswa cukup kuat untuk melahirkan wirausaha- wirausaha baru seperti sering terungkap dalam teori-teori yang dikemukakan para ahli. Kuatnya intensi kewirausahaan ini menunjukkan adanya keyakinan mahasiswa untuk terjun berwirausaha. Hal ini merupakan 
kabar baik untuk meminimalisir tingkat pengangguran yang reltif tinggi yaitu sekitar 40\% (Kristiansen, 2003) dan proses pengembangan perekonomian yang masih sangat bertumpu pada UMKM dalam skala kecil. Dengan demikian Indonesia sangat berkepentingan untuk mendorong lahirnya wirausahawirausaha baru dari kalangan perguruan tinggi. Oleh karena itu, selain dengan cara meningkatkan efektivitas pendidikan kewirausahaan di perguruna tinggi, pemerintah perlu merumuskan regulasi yang memihak kepada kepentingan pewirausaha pemula seperti penyedia modal.

\section{Deskripsi Intensi Kewirausahaan} Mahasiswa

Secara rinci deskripsi ntensi kewirausahaan dalam pembahasan hasil penelitian setiap dimensi :

a. Sikap terhadap Kewirausahaan

Untuk mengukur sikap mahasiswa terhadap kewirausahaan ini mengembangkan skala sikap dengan lima opsi jawaban yang mencerminkan kecenderungan sangat setuju, setuju, netral, tidak setuju dan sangat tidak setuju. Pengukuran sikap mahasiswa terhadap kewirausahaan yang terdiri dari sikap terhadap profesi wirausaha, aktivitas berwirausaha dan sikap terhadap pilihan karir berwirausaha dilakukan melalui lima pernyataan yaitu : 1) Profesi sebagai wirausaha merupakan profesi yang terhormat, 2) Setelah lulus nanti saya akan memprioritasakan untuk berkarir sebagai wirausaha dibanding sebagai karyawan, 3) peluang untuk berwirausaha saat ini terbuka lebar, 4) berwirausaha itu mudah, asal mau bekerja keras pasti berhasil dan 5) berwirausaha itu sangat menantang. Hasil penelitian menunjukkan bahwa sikap terhadap kewirausahaan pada kelima pernyataan tersebut berada di kategori tinggi atau positif dengan angka rata-rata 4,07. Artinya dalam menilai dimensi-dimensi kewirausahaan, mayoritas mahasiswa memandang sesuatu yang positif dan berkeyakinan terhadap profesi wirausaha.

\section{b. Norma sosial yang dirasakan}

Persepsi tentang norma sosial yang dirasakan didefinisikan sebagai respon individu terhadap tekanan sosial dan hambatan sosial terhadap keinginan berprilaku yang berasal dari sistem nilai dan norma sosial yang dirasakannya. Hal ini berlaku juga dalam konteks keinginan untuk berwirausaha. Seorang individu akan melemah keinginannya untuk berwirausaha bila sistem nilai dan norma-norma sosial yang berlaku pada masyarakatnya cenderung menganggap rendah atau tidak menghargai aktivitas berwirausaha. Sebaliknya bila sistem nilai dan norma-norma sosial di masyarakatnya cebderung menganggap aktivitas berwirausaha adalah sesuatu yang baik dan 
terhormat maka keinginan untuk berwirausaha dari anggota masyarakatnya akan cenderung meningkat.

Dalam penelitian ini, pengukuran terhadap persepsi tentang norma-norma sosial yang dirasakan oleh mahasiswa dilakukan melalui lima pernyataan, yaitu : 1) profesi sebagai pegawai (negeri/swasta) lebih disukai dibanding profesi sebagai wirasusaha, 2) profesi wirausaha adalah profesi yang bisa di andalkan untuk masa depan anak-anaknya, 3) kebiasaan atau tradisi (pesta misalnya) yang sifatnya hura-hura dan pemborosan, 4) menanamkan kebiasaan untuk hidup hemat dan membiasakan menabung dan 5) Di lingkungan masyarakat sekitar saya terdapat wirausahawan yang sukses yang dapat menginspirasi atau mendorong anda mengikuti jejaknya.

Hasil penelitian memperlihatkan bahwa mahasiswa merasa norma-norma sosial yang hidup dan berkembang di lingkungan masyarakat mereka masing-masing berada pada kategori tinggi dengan angka rata-rata 3,65 dalam memandang kewirausahaan. Hal in berarti norma-norma sosial di lingkungan masyarakat tempat mahasiswa berada cukup mendukung dan juga tidak menghambat kewirausahaan. c. Efikasi Diri

Konsep efikasi diri (selfefficacy) yang diduga dapat mempengaruhi intensi kewirausahaan pertama kali dikemukakan oleh Shapero dan Sokol (1982) dalam teori yang kemudian dikenal sebagai Theory of Entrepreneurial Event (TEE). Menurut Bandura (Friedman dan Schustack, 2008), fikasi diri menentukan : 1) apakah seseorang akan menunjukkan perilaku tertentu, 2) sekuat apa ia dapat bertahaan saat menghadapi kesulitan atau kegagalan, dan 3) bagaimana kesuksesan atau kegagalan dalam satu tugas tertentu dipengaruhi perilakunya di masa depan.

Dalam penelitian ini, pengukuran efikasi diri dilakukan melalui delapan item pernyataan yang mewakili tiga indikator, yaitu : 1) keyakinan akan potensi diri, 2) keyakinan akan kesuksesan usaha yang dirintisnya dan 3) keyakinan akan tetap survive dalam usahanya. Hasil penelitian memperlihatkan bahwa tingkat efikasi diri mahasiswa untuk menjadi pewirausaha berda pada kategori tinggi dengan angka rata-rata 3,73. Hal ini ditafsirkan bahwa mayoritas mahasiswa memiliki keyakinan yang kuat untuk terjun menjadi pewirausaha. Kayakinan mahasiswa ini tentu merupakan fakta yang bisa menjadi masukan bagi perguruan tinggi untuk semakin meningkatkan intensi 
kewirausahaan di kalangan mahasiswa.

Studi mengenai intensi kewirausahaan mahasiswa masih terbuka luas untuk dielaborasi dalam berbagai konteks. Untuk kelompok jenis kelamin dan bidang studi merupakan faktor-faktor yang diteliti dalam studi ini karena studistudi yang sudah dilakukan terdahulu belum memperlihatkan arah yang jelas. Faktor jenis kelamin dalam beberapa penelitian memperlihatkan berpengaruh terhadap intensi kewirausahaan mahasiswa, yaitu mahasiswa (laki-laki) memiliki intensi berwirausaha yang lebih tinggi daripada mahasiswi (perempuan) (Rasheed, 2000; Nishanta, 2008). Dalam penelitian ini, justru yang terjadi adalah sebaliknya yaitu mahasiswa (lakilaki) memiliki intensi berwirausaha yang lebih tinggi daripada mahasiswi (perempuan). Hal ini dapat menjadi indikasi bahwa calon wirausaha muda terdidik tidak dibatasi oleh jenis kelamin. Data pelengkap yang diperoleh dalam penelitian ini menunjukkan sebagian besar responden mahasiswi telah menjalankan praktek berwirausaha sambil berkuliah dalam bentuk usaha online secara online dan terdapat kesan mahasiswi lebih luwes dalam berwirausaha sambil kuliah ketimbang para mahasiswa.

\section{KESIMPULAN}

Intensi kewirausahaan di Indonesia khususnya di perguruan tinggi negeri kota Bandung termasuk dalam kategori tinggi. Semakin tinggi sikap, norma sosial dan efikasi diri mahasiswa semakin tinggi tingkat intensi kewirausahaan. Artinya intensi kewirausahaan yang dimiliki mahasiswa sudah menunjukkan respon yang positif terhadap kewirausahaan.

\section{DAFTAR PUSTAKA}

Alma, Buchori. (2011). Kewirausahaan. Bandung: Alfabeta.

Ciputra. (2007). "Entrepreneurial Education to Solve The Problem of Poverty and Unemployment in Indonesia". Makalah disampaikan pada INA-ICDF International Seminar. Institut Pertanian Bogor 11 Maret 2010.

Choo S, dan Wong M. 2006. "Entrepreneurial intention: triggers and barriers to new venture creations in Singapore". Singapore Management Review. 28: 4764

Hendarman. (2011). Kajian Kebijakan PMW (Program Mahasiswa Wirausaha) dalam Jurnal Pendidikan dan Kebudayaan Vol. 17. No. 8. Edisi November 2011, Balitbang, Kemdiknas, Jakarta. Kristiansen, Stein dan Pratikno. $2006 . \quad$ Decentralisation

Education in Indonesia. Gajahmada University. Volume 26 Nomor 26: 513- 
531.

Katz J A. (2003), “The chronology and intellectual trajectory of American entrepreneurshipeducation", Journal of Business Venturing, Vol.18 No.2, pp.283-300.

Krueger, N. (1993). The Impact of Prior Entrepreneurial Exposure on Perceptions of New Venture Feasibility and Desirability. Entrepreneurial Theory Practice, 18(1): 5-21.

Mukhamad Azhar, Suwatno, Amir Machmud .(2018).

Determinant Return To Education In Indonesia MANAJERIAL Vol 3, No 4: Kompetensi, Motivasi dan Pembelajaran

Rasheed, H.S. 2000. Developing Entrepreneurial Potential in Youth: The Effects of Entrepre-neurial Education and Venture Creation, (http://USASEB2001proceedin gs063, di akses 25April 2018)

Sugiono. (2012). Metode Penelitian Kuantitatif Kualitatif dan $R \& D$. Bandung: Alfabeta.

Suwatno, A. Sobandi, Rasto. (2012). Implementasi Proses Pembelajaran Dalam Mencapai Kompetensi Guru Bidang Keahlian Manajemen Perkantoran. MANAJERIAL Vol 10, No 20 Kependidikan, Manajemen: Teknologi Informasi, Bisnis. 